\author{
Asrat Dagnew ${ }^{1}$ \\ College of Education and Behavioural Science \\ Bahir dar University \\ Ethiopia
}

Original scientific paper

UDK: 37.013

DOI: $10.17810 / 2015.74$

Creative Commons

Attribution 4.0

International License

\title{
TEACHERS' AND STUDENTS' PERCEPTIONS AND PRACTICES ON PEER-LED LEARNING AT GHION SECONDERY AND PREPARATORY SCHOOL OFBAHIR DAR CITY, ETHIOPIA
}

\begin{abstract}
The general purpose of this study was to examine teachers' and students' perceptions and practices of peer-led learning in Ghion secondary and preparatory school in Bahir Dar City, Ethiopia. To conduct the research, quantitative and qualitative methods were employed. The sample of the study was taken from the population of 41 teachers and 629 students. Proportional stratified sampling technique was used to limit number of respondents of the sample groups.All 41 teachers and 189 students (grade $9^{\text {th }} 102$, grade $10^{\text {th }} 69$, and grade $11^{\text {th }} 12$, \&grade $12^{\text {th }} 6$ ) were included in the sample. The main instruments of data collection were both open-ended and close-ended questionnaires. The findings of the study revealed that teachers and students have perceived peer-led learning positively. In spite of their good perceptions, their practices of peer-led learning were low. The opportunities to strengthen peer-led learning were teachers' and students' positive perceptions and distribution of check lists in the school. To conclude, school teachers and students have positive perceptions and low practices of peer-led learning. There is no significant difference in their perceptions. Based on the major findings, the researcher recommended minimizing problems encountered and maximizing the implementation of peer-led learning.
\end{abstract}

Key Words: Teachers, students, perception, practice and peer-led learning.

\section{INTRODUCTION}

Peer-led learning refers to techniques where students do more activities in groups than only receiving every thing from the teachers. Students are doing thing which include discovering, processing, and applying information. Today, educators feel that traditional methods of teaching are not sufficient. Because, the traditional method has positioned the students as passive receptors in which teachers deposit concepts and information and emphasize rote memory for the students. This method of instruction or teaching is not sufficient to develop the required skills (Dori\&Beclcher, 2005).

The small-group, peer-led problem-solving model can also provide benefits by virtue of its emphasis on solving problems, as opposed to exclusively listening to or reading information. Because students are led by their peers, their learning can be more effectively scaffolded than it often is in the professor-led classroom, with leaders guiding students from a level just slightly above their current level of understanding, rather than from far beyond their current

1asratboza@yahoo.com 
level (Vygotsky, 1978). Students practiced peer-led learning in the class were told to sit in the form of circle. A significant proportion of a lesson is distributed to every group to do activities such as problem-solving, simulation, laboratory investigations, researching websites to practice and acquire skills (Beichner et al. 2000).

Concerning peer-ledlearning, the extent to which teachers and students understand the concept and the skills they have to implement are essential conditions. The tendency to focus on the instructors' reluctance to use teaching innovations, mainly to promote active learning, in order to explain the lack of use of these innovations neglects another important component i.e. the students' expectations from learning. In many cases, students prefer an instruction style that allows their passive participation in the lesson and where the instructor presents the learning material in a clear manner and solves all the problems expected to be included in the final exam for them (Slater, 2003). The students like instructors who are used to traditional learning, are not eager to adapt to new learning environments. Consequently, instructors who enthusiastically adopt new methods are often frustrated by their students' responses (Felder and Brent, 1996)

Numerous studies have been undertaken in recent years regarding instructors' perceptions of their function in academic institutions. Some researchers have identified a distinction between perceptions focused on the instructor regarding the transmission of knowledge and information, perceptions focused on the instructor-student relations, and perceptions focused on the students' activities and the development of understanding and conceptualization (Gerlese\&Akerlind, 2004).

Over the past decade, researchers and instructors in Ethiopia and around the world have attempted to promote active learning particularly peer-led learning in academic courses. The process of introducing innovation in teaching based on the adoption of active teaching approaches is a long and complex one. In many fields of teaching, it is a challenge to introduce innovations even when this would clearly be advantageous and beneficial (Dori, et al. 2003).

The active learning environments included group activities done by students during the lecture, problem-solving, laboratory investigations, researching websites, conceptual tests, peer teaching (Mazur, 1997), active demonstration (Cooper and Robinzon, 2000), simulations (Dori, et al. 2003), group problem solving (Redish, 2003) and 'just in time' teaching (Beichner, et al. 2000).

Since the writer is an instructorat the Bahir Dar University, he observed teachers and studentswho did not practice the new and innovative methods of teaching and learning process to bring up the quality of education by recognizing the dynamic nature of students.

The problems emanated from the perceptions of the school communities have influenced peer- led learning and the way it is practiced in the school. Thus, the study mainly aimed to investigate teachers' and students' perceptions and practices of peer-led leaning.

There have been very few published papers so far that have reported on students' perceptions of group work. One recent exception has been a paper by (Colbecket al. 2000) who reported that prior influences such as the amount of instruction that the students received and the degree of group-work experience that they had previously undertaken affected the amount of interdependency constructed between the group members. This in 
turn was related to how important the students' perceived peer-led learning participation to be, as a means of aiding the development of career-related skills.

The Ministry of education in its sector development program III (2010/2011) document indicates that the school improvement program indicates student-centered learning, professional development and collaboration among the major focus areas. The quality of the instructional program is also one of the most significant points. However, the implementation of peer-led learning is still very low.

This research has been designed due to the current different research results showed in consistent projects in Ethiopian secondary schools. Therefore, to fill the gap found among studies, the researcher investigated teachers' and students' perceptions and practices of peer-led learning.

In light of the above explanation, the study focused on answering the following basic research questions:

1. What are the teachers' and students' perceptions of peer-led learning?

2. What are the current teachers' and students' practices of peer-led learning?

3. Is there a significance difference between teachers' and students' perceptions of peer-led learning?

4. What are the opportunities to implement peer-led learning in the school?

5. What are the challenges to implement peer-led learning in the school?

The general objectives of this study was to show teachers' and students' perceptions and practices of peer-led learning in Ghion Secondary and Preparatory School of Bahir Dar city. Accordingly, this study focused on the following specific objectives to identify teachers' and students' perception of peer-led learning, to show the current practices of peer led learning in the school, to examine the existing differences between teachers' and students' perception about peer led learning in the school, to assess the present opportunities for implementing peer-ledlearning in the school and to investigate the existing challenges of peer-led learning in the school.

\section{MATERIALS AND METHODS}

The main purpose of this study was to identify the teachers' and students' perceptions and practices of peer-led learning in Ghion secondary and preparatory school ofBahir Dar city. To accomplish the research, the study was conducted based on a descriptive research design.

\section{Source of Data}

For this study, primary sources of data were employed. The primary sources were teachers, and students of Ghion secondary and preparatory school in Bahir Dar city. 


\section{Population, sample and sampling technique}

Table 1: Sample of students' included in the study from each grade level.

\begin{tabular}{llllllll}
\hline $\begin{array}{l}\text { List of grade } \\
\text { level }\end{array}$ & $\begin{array}{l}\text { Total number of } \\
\text { sections }\end{array}$ & $\begin{array}{l}\text { Total number of students } \\
\text { registered }\end{array}$ & \multicolumn{3}{l}{$\begin{array}{l}\text { Number of sample students from } \\
\text { each grade level }\end{array}$} \\
\cline { 3 - 8 } & & $\mathrm{M}$ & $\mathrm{F}$ & $\mathrm{T}$ & $\mathrm{M}$ & $\mathrm{F}$ & $\mathrm{T}$ \\
Grade $^{\text {th }}$ & 7 & 195 & 149 & 344 & 58 & 44 & 102 \\
Grade 10 $^{\text {th }}$ & 4 & 144 & 85 & 229 & 43 & 26 & 69 \\
Grade 11 th $_{\text {Grade 12 }}^{\text {th }}$ & 2 & 20 & 18 & 38 & 6 & 6 & 12 \\
Gotal & 2 & 9 & 9 & 18 & 3 & 3 & 6 \\
\hline
\end{tabular}

Source: Ghion secondary and preparatory school record office 2017

Ghion secondary and preparatory school students, who registered in 2017, consisted of 368 males and 261 females with a total number of629. Furthermore, 41 teachers participated in this study. For this research, asample of 189 students (110 males and 79 females) was selected randomly. Multistage proportional stratified sampling technique was employed. To obtain valid information all teachers in the school,that is 41 teachers ( 31 males and 10 female), were selected purposively.

\section{Data Gathering Instruments}

The researcher used questionnaires to gather the data.To obtain reliable and valid data for the study closed-ended questionnaires for all teachers and students were prepared. The researcher used similar questionnaires for both teachers and students but with a different formulation. They contained sixty items of a 5 point Likert scale type about perceptions and five items 4 point Likert scale type about practices of peer-led learning. The remaining questions identified about the existing opportunities and challenges of peer-led learning were constructed as four open-ended questions for both teachers and students.

\section{Techniques of Data Analysis}

The data collected by closed-ended questions were analyzed in quantitative while the data obtained through open-ended questions were analyzed in qualitative techniques.

Two sample t-test and one sample t-test analysis were used to analyze the data. Two sample ttests were used to examine the significance of the difference level of teachers' and students' perceptions about peer-led learning.

Furthermore, one sampled t-test was used to test general levels of perceptions and practices of teachers' and students' independently, regarding peer-led learning. Finally, the data obtained from open-ended questions were analyzed qualitatively using the descriptive method.

\section{RESULTS}

\section{Teachers' perceptions about peer-led learning in the school}

To observe the general levels of teachers' perceptions about peer-led learning, one sample ttest was used and the results are presented in table 2 below: 
Table 2: The teachers' perceptions about peer-learning

\begin{tabular}{lllllllll}
\hline Variable & Participants & Mean & SD & $\begin{array}{l}\text { Expected mean } \\
\text { score }\end{array}$ & $\begin{array}{l}\text { t } \\
\text { value }\end{array}$ & $\begin{array}{l}\text { t-critical } \\
\text { value }\end{array}$ & $\begin{array}{l}\text { p- } \\
\text { value }\end{array}$ \\
\hline $\begin{array}{l}\text { Teachers' } \\
\text { perceptions }\end{array}$ & $\begin{array}{l}\text { Teachers } \\
(41)\end{array}$ & 64.34 & 3.74 & 48 & 27.93 & 2.021 & $<0.05$ \\
\hline
\end{tabular}

$d f=40$

As indicated in table 2, the result of the t-test on teachers' perception of peer-led learning was implemented to identify the level of significance. The mean score of the teachers' measure of perceptions of peer-led leaning was greater than the expected mean score which indicated that teachers have high perceptions about peer-led learning in the school at $t=27.93, d f=40$, $p=0.00$. Since the obtained $t$-value is greater than the critical value, the perception level of teachers is significantly different.

\section{Teachers' practice of peer-led learning in the school}

To demonstrate the degrees of teachers' practice of peer-led learning in the school, one sample t-test was used and the results are presented in table 3.

Table 3: Teachers' practice of peer-led learning in the school

\begin{tabular}{llllllllll}
\hline Variable & Participants & Mean & SD & $\begin{array}{l}\text { Expected } \\
\text { score }\end{array}$ & $\begin{array}{l}\text { mean } \\
\text { t } \\
\text { value }\end{array}$ & $\begin{array}{l}\text { t-critical } \\
\text { value }\end{array}$ & $\begin{array}{l}\mathrm{p} \text { - } \\
\text { value }\end{array}$ \\
\hline $\begin{array}{l}\text { Teachers' } \\
\text { practices }\end{array}$ & $\begin{array}{l}\text { Teachers } \\
\text { (41) }\end{array}$ & 10.804 & 1.5 & 12.5 & & -7.218 & 2.021 & $<0.05$ \\
\hline
\end{tabular}

$d f=40$

As results presented in the table 3 indicate, the level of teachers' involvement in peer-led learning showed was significantly less than the expected. The low mean values $t=7.218, d f=$ $40, p=0.000$ revealed that teachers were less engaged in peer-led learning method in the school.

\section{Students' perception level about pee-led learning}

To see students' level of understanding about peer-led learning in the school, one sample ttest was used and the results are presented in table 4:

Table 4: Students' perceptions about peer-led leaning

\begin{tabular}{lllllllll}
\hline Variable & Participants & Mean & SD & $\begin{array}{l}\text { Expected mean } \\
\text { score }\end{array}$ & $\begin{array}{l}\text { t } \\
\text { value }\end{array}$ & $\begin{array}{l}\text { t-critical } \\
\text { value }\end{array}$ & $\begin{array}{l}\text { p- } \\
\text { value }\end{array}$ \\
\hline $\begin{array}{l}\text { Students' } \\
\text { perceptions }\end{array}$ & Students(189) & 62.613 & 5.46 & 48 & 36.769 & 1.97 & $<0.05$ \\
\hline
\end{tabular}

$d f=188$

As the results of table 4 indicate, the mean difference obtained is greater than the expected mean score which shows that the students' perception regarding peer-led learning is significantly greater than the average expected mean at $t=36.769, d f=188, p=0.00$.

This implies that the students' perception is high towards peer-led leaning. They have knowledge or understanding about peer learning. 


\section{Students' practice of peer-led leaning in the school}

To understand the significance level of students' practice of peer led learning one sample ttest was used and the results are presented in table 5 below.

Table 5: Students' practice of peer-led learning

\begin{tabular}{llllllllll}
\hline Variable & Participants & Mean & SD & $\begin{array}{l}\text { Expected } \\
\text { score }\end{array}$ & mean & $\begin{array}{l}\text { t } \\
\text { value }\end{array}$ & $\begin{array}{l}\text { t-critical } \\
\text { value }\end{array}$ & $\begin{array}{l}\text { p- } \\
\text { value }\end{array}$ \\
\hline $\begin{array}{l}\text { Students' } \\
\text { practice }\end{array}$ & $\begin{array}{l}\text { Students } \\
\text { (189) }\end{array}$ & 11.55 & 2.3 & 12.5 & & 5.67 & 1.97 & $<0.05$ \\
\hline
\end{tabular}

$d f=188$

In table 5, the obtained data indicated that the mean value is less than the expected mean value of students' engagement in peer-led learning, which justified that students had significantly less practice in peer-led learning at $t=-5.67, \mathrm{df}=188, \mathrm{p}=0.00$. This result implies that students are not always used to peer led learning.

\section{Differences of teachers' and students' perceptions toward peer led learning}

The study compared the average score of teachers' $(\mathrm{N}=41)$ with the average score of students' ( $\mathrm{N}=189)$ perceptions concerning peer-led learning. The comparisons of averages were undertaken using independent t-test analysis. Table 6 , presents the results of the comparison.

Table 6: Teachers' and students' perceptions differences toward peer-led learning

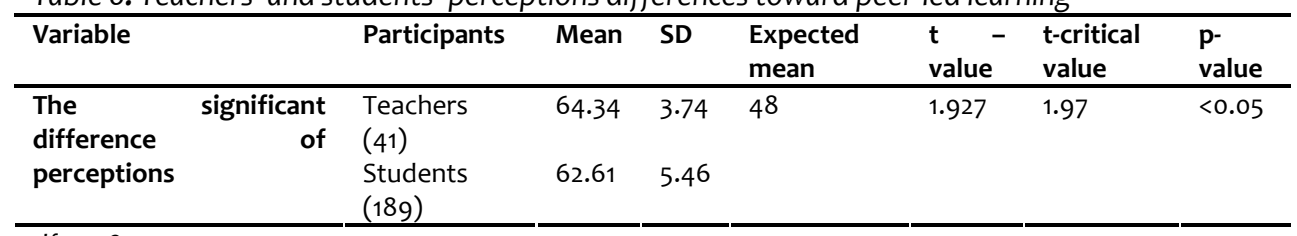

$d f=228$

As indicated in table 6, the findings of the study show that the teachers' perceptions towards peer led learning have a greater mean value than students' perceptions towards peer-led learning and the obtained $t$-value is less than the critical value. This implies that the difference between two means were not significant at $t=1.927, d f=228, P=0.038$ in favor of teachers' perceptions.

\section{The opportunities and challenges of peer-led learning}

In addition to those close-ended questions about teachers' and students' perceptions and practices of peer-led learning; the study also employed open-ended questions to find out the opportunities and challenges of peer-led learning in the school.

Comparatively, all responses of the respondents constantly illustrated the main advantages of peer-led learning in the school. The current education policy is supportive as students attend their education based on the structurally pre-arranged peer-led team learning groups. However, there is no commonly identified national standard that helps to implement peer-led learning. Occasionally, the school administrations distribute different check lists for teachers 
regarding how to practice peer-led learning. Above all, the major opportunity of peer-led learning is lies in the current agenda for the education staff which lets the school exchange best experiences from other schools or within the school.

To overcome the problem / limitation related to peer-led learning the responses of the respondents were analyzed as follows:

Most of the respondents indicated that the school employs different reinforcements for the best peer-led learning practiced teams. Include the school in experience sharing within the groups and with other schools, create a cooperative environment for students instead of forming only a competitive environment, the school should continuously be working with the community. Whereas a few respondents indicated that district experts must give instructional support or supervision for peer-led learning practice, to provide capacity building training for teachers and students, the school must design a workable and participatory plan and the school must prepare different appropriate spaces in the school compound which provide peer-led learning services.

It was difficult to write all the responses because; the data was analyzed qualitatively in the descriptive research method with the great protection of the original ideas of the respondents.

As to the support of the school furnished to implement peer-led learning most respondents reported that although peer-led learning existence in the school is vital for a number of reasons, the school did not support peer-led learning, there was an absence of continues follow up, lack of commitment \& reinforcement, inadequacy of the school plan and an inability to working together with the community.

Participants of the study were also asked to report the main challenges in the school to practice peer-led learning. More or less all respondents reported that the challenges of peerled learning were due to the schools lack of continues follow up to enhance peer led learning groups, absence of recognition for relatively better understanding and practices of peer-led teams, low value of the benefits obtained through peer led learning, the inadequacy of the participatory peer-led plan, inability to utilize peer-led leaning outside the classroom, no cooperation with students' families, the formation ofa competitive environment in the school, the inability to find an appropriate place to study and to have group discussions and most members of the peer-led team did not attend their classes and did not even stay in the school compound.

\section{DISCUSSIONS}

\section{Teachers' perceptions about peer-led learning}

This study revealed that teachers' have positive perceptions of peer-led learning, while there exist significant differences in their perceptions.

Regarding teachers' and students' perceptions various research findings confirmed that there is a strong tie between peer-led learning and implementation. For instance, some survey studies conducted previously, indicated that instructors and students who had a positive attitude towards peer-led learning showed a better effort in implementing and using 
peer-led learning than those instructors and students who perceived peer-led learning negatively. Similarly, Mazur, E. (1997) showed that teachers' attitudes have a great influence in the effective implementation of peer-led learning. In line with these ideas, sixteen statements for the instructors and fourteen statements for the students were included in the questionnaires with the intention of assessing their knowledge or perception of peer-led learning. Hence, it appeared that almost all of the instructors and students showed their agreement and strong agreement with the assumption of peer-led learning raised in the questionnaires.

The research finding which show similar results with teachers' perceptions indicate that instructors were eager to implement peer-led learning and to adapt new learning environments in the school compound. Consequently, instructors who enthusiastically adopt peer-led learning methods are often frustrated by their students' responses (Felder and Brent 1996). The implications of this study are that teachers have a great interest to adopt peer-led leaning but have no power to overcome the students' resistance. Both teachers and students rarely implement peer-led learning in practice.

Researchers like Mello (1993), who had performed extensive studies in peer-led learning, showed that peer-led learning has great benefits. Peer-led learning in group-work allows the instructor to develop more comprehensive assignments. The findings of this study reveal that teachers are willing to implement peer-led learning because of the benefits they obtained from peer-led learning.

In such situations, it is possible to say that teachers should put in effort to the effective application of the peer-led learning when they expected certain benefits from peer-led learning.

\section{Teachers' practice of peer led learning in the school}

The findings of this study reveal that Ghion secondary and preparatory school teachers were not involved in peer-led learning as expected. However, they have high perceptions of peerled learning.

The following research findings indicate the major reasons why teachers and students are unable to practice peer-led learning regularly in the school. In a study that interviewed teachers (Niemi, 2002), the respondents noted six factors/ variables that they felt prevented them from engaging in teaching that promotes peer-led learning: A) Lack of time due to the need to complete all the required material in a packed curriculum. B) Teaching in large groups does not permit active teaching. C) A shortage of instructional materials suitable for the active teaching approach. D) Opposition among senior colleagues to changes after they have developed teaching methods suited to their capabilities and experience. E.) A lack of metacognitive skills and motivation on the part of the students. F) Among high school teachers, parental opposition to change was also mentioned. In addition to these factors/variables, teachers argue that difficulties occur in the assimilation of active learning when students lack background knowledge in the studied subject. 


\section{Students' perception of peer-led learning}

The findings of this study indicated that the students' perceptions were high regarding the benefits of peer-led learning regarding: the enhancement of their interest for learning, its benefit for group assessment, the understanding of new and complex material, awareness of alternative problem-solving strategies and the fact that it makes students active and eager.

The result of this study is similar to the finings of some studies which explored the perception of peer-led learning in different disciplines. Curran, et al. (2013) from his research study about how changing attitudes facilitates understanding in the undergraduate statistics classroom: Inthe collaborative learning approach, the students enrolled in the undergraduate statistics classroom with positive attitudes which promoted high expectations for their own competence and performance. The findings of this study showed that those students have developed positive attitudes towards peer-led learning and therefore they were successful in the statistics course and engaged in peer-led learning.

Research which has examined the collectivist/individualist nature of cultures has shown that students from collectivist cultures, for example Japan, China and Korea, value goals and interests related to the cultural group, whilst students from individualistic cultures, for example America and Britain, orient towards personal aspirations influenced the level of students involvement in peer-led learning (Milhouse, 1996). According to this finding, the perceptions of the students toward peer-led learning depend on the cultures they come from. Because of this, the students who come from very sociable and democratic societies have positive perception about peer-led leaning while students who come from very restricted and unsociable societies have negative perceptions in relation to the engagement in peer-led learning.

Research findings show that students are unable to create a positive reaction to peer-led learning. Team study investigated by Colbeck, et al. (2000) indicated that some students have been found to display negative reactions to group learning experiences, especially when they believe the tutor had poor group skills or did not help the group.

Scholars found that students believed the peer-led workshops stimulated interest in the course, enhanced critical thinking and problem-solving skills, decreased student anxiety, and created a safe environment for learning to occur, which is consistent with the findings of this research.

The research conducted by Abson (1994), also reported evidence that peer assessment could be used as a means of legitimizing prejudice and discriminatory practices against individual students. According to the research findings, students were involved in peer-led learning faced ignorance and loss of acceptance from their team members. Therefore, majority of the students in the school are not interested to participate in peer-led learning.

\section{Students' practices of peer-led learning}

The final finding of the present study, represented in table 6, show that students were not regularly involved in peer-led learning. The result indicated that Ghion Secondary and preparatory school students' engagement was low regarding the practice of peer-led learning in the school. 
In the previous studies reported by Cheng and Warren, (1997) and Burnett and Cavaye, (1980), many students felt uncomfortable about the practices of peer-led learning. In relation to the qualitative responses, there were far more written responses to the group-work scale than to the peer assessment scale. This study clearly showed that students have no interests to get involved in peer-led learning teams. The second study investigated by Burnet and Cavaye (1980) showed that students have been reported as disliking being given the responsibility for awarding marks to their peers. In this study students had no interests to work with each other's and resisted engagement in peer-led learning since they were evaluated in groups.

This study has its own implication for the teaching learning process and for strengthening the quality of professional personnel in secondary schools. The major activities contributing to the achievement of this result includes the use of peer-led learning.

As we have seen from table 6 , teachers and students have significantly positive perceptions which acknowledge the importance of peer-led learning. But, they do not use peer-led learning in the school. In peer-led learning, group members work together and acquire knowledge through their struggle to maintain equilibrium, a process involving the reconciliation of conflict between new and previously held beliefs (Foot and Howe, 1998). Teachers and students should be encouraged to reflect on the value premises they hold and the practical knowledge and skill teachers acquire which enables students' to practice peerled learning.

\section{Differences in teachers and students perceptions toward peer-led learning}

The result of this study showed that teachers and students have significantly similar positive perceptions about peer-led learning in the school.

Similarly, the study is in line withother studies which were done by Cracolie and Trautman (2001) in cooperative learning that deals with small groups of students, their achievement and perceptions. According to this study, teachers and students suggest that peer-leaders and other students should provide the social support to foster learning. The result of the study indicated that both teachers and students have a positive attitude towards the existence of peer led learning methods in the school.

According to the findings of Foot and Howe (1998), research investigation on collaborative learning shows that group members work together and acquire knowledge through their struggle to maintain equilibrium, a process involving the reconciliation of conflict between new and previously owned beliefs. Hence, the finding of the research indicated that the perceptions of peer-led members regarding peer-led learning methods depended on their previous academic background.

Findings of the study revealed that challenges of peer-led learning such as schools having no continues follow up to enhance peer-led learning groups, absence of recognition for relatively better understanding and practices of the peer-led team, providing low value for the benefits that are obtained from peer-led learning, inadequacy of participatory peer-led designed plan, low inclinations of school communities to engage students in peer-led leaning outside the classroom, unable to cooperate with students family to utilize peer-led leaning programs, the formation of a competitive environments instead of creating cooperative environments in the school, inability to find an appropriate place to study and to discuss together in the school 
compound and most members of the peer-led members did not attend their classes and did not even stay in the school compound.

Like any other educational issues in the teaching-learning process, it is also possible to think that active learning may have shortcomings or constraints during its implementation in real classroom conditions. From these constraints, the researcher has selected the most serious possible factors affecting the implementation of active learning in the school. These factors were selected on the basis of their frequency in the responses of the instructors and students. Shortage of time is among these factors. With respect to this problem the two groups of respondents agreed that the time table was the major problem negatively affecting the implementation of active learning. Supporting this fact, Farant (1980) explains the effect of time. The author stresses that shortage of time limits instructors and students from implementing active learning in the classroom. In this study, the instructors' tendency towards the traditional lecture method is blamed as an obstacle in the implementation of active learning by many students and some instructors. With respect to this problem, the two groups of respondents (teachers \& students) again agreed that the tendency of instructors and preference for the traditional methods of teachers' explanations or lecture was the major problem negatively influencing the effective implementation of active learning.

\section{Conclusion}

The main purpose of this study was to show the teachers' and students' level of perceptions and practices of peer-led learning and to identify the problems that hinder peer-led learning in the school. Furthermore the existing opportunities that enable effective utilization of peer-led learning at Ghion secondary and preparatory school of Bahir Dar city were indicated.

Both teachers and students of Ghion secondary and preparatory school of Bahir Dar city have high perceptions and low practices of peer-led learning and no significant difference in their perceptions were found.

\section{ACKNOWLEDGEMENTS}

I would like to thank the administrative bodies of Ghion Secondary and preparatory school organization which gave me permission to gather data for the study. It is also my pleasure to thank grade $9,10,11 \& 12$ students who voluntarily participated in the study. I also want to express my deepest gratitude to the school principal, vice principal, supervisor and teachers who actively participated in data collection.

\section{References}

Abson, D. (1994). The effects of peer evaluation on the behavior of undergraduate Students working in tutorless groups: The case of H.C. Unpublished Master's thesis A.K.

Beichner R.J., Saul J.M., Allain R.J., Deardorff D.L., Abbott D.S. (2000). Promoting Collaborative groups in large enrollment courses, Proceedings of the Annual Meeting of the American Association of Physics Teachers, American 5-8, June, 
pp. 172 - 121, AG.

Burnett, W. and Cavaye, G. (1980). Peer assessment by fifth-year students of surgery: Unpublished Assessment in HigherEducation, Seekery.

Cheng, W., and Warren, M. (1997). Having second thoughts: student perceptions before and after a peer assessment exercise. Studies in Higher Education Unpublished pepare in TU.

Colbeck, C.L., Campbell, S.E. and Bjorklund, S.A. (2000). Grouping in the dark: What college students learn from group projects. The Liely Journal of Higher Education. Vol. 71, No.1 pp. 60-83.

Cooper J.L., Robinson P. (2000). The arguments for making large classes seem small. The Journal of New Directions forTeaching and Learning. Vol.81, No.2, PP.5-16.

Cracolice, M.S., \&Trautman, T.A. (2001).Vygotsky's theories of education: Theory bases for peer-led team learning. In D.K: Gosser, M.S. pub.

Curran, K.C., \&Dayius T. C. (2013). Changing attitude and facilitating understanding in the undergraduate statistics classroom: A collaborative learning approach. The Journal of the scholarship of teaching and learning. Vol.13, No.2, pp 49-71

Dori Y.J., Belcher J.W. (2005). How does technology-enabled active learning affect students' understanding of scientific concepts?. Journal of Learning Science. Vol. 14, No.2, PP. 243-279.

Dori Y.J., Belcher J.W., Bessette M., Danziger M., McKinner A., and Hult E. (2003). Technology for active learning.Journal of Mater Today. Vol. 6, No. 12, PP. 44-49.

Farant,J.S. (1980). Principles and Practice of Education. Singapore: Longman pup.

Felder R.M., and Brent R. (1996). Navigate the bumpy road to student centered instruction. Journal ofCollege Teach. Vol. 44, No. 5, PP. 43-47.

Foot, R., and Howe, C. (1998).The psycho educational basis of peer-assisted learning: Peer assisted Learning. London: Lawrence Erlbaum Associates. Topping and S. Ehly pub.

Gerlese, S., and Akerlind, G.S. (2004). A new dimension to understanding university teaching. The journal of higher educ. Vol. 9, No. 3, PP. 363-375.

Mazur, E. (1997). Peer Instruction. Upper Saddle River, N: prentice pub.

Mello, J.A. (1993). Improving individual member accountability in small work settings. Journal of Management Education. Vol. 71 No.2, pp. 253-259.

Milhouse, V.H. (1996). Intercultural strategic competence: An effective tool collectivist and individualist students can use to better understand each other. Journal of Instructional Psychology, pp. 45-54.

Niemi, H. (2002). Active Learning - A cultural change in teacher education and schools. Journal of Teacher Educ. Vol.18, No.3, PP. 763-780.

Redish, E.F. (2003).Teaching physics with the Physics Suite: Hoboken, NJ: Wiley Pub.

Salomon, G. and Globerson, T. (1989). When teams do not function the way they ought to. In N.M. Webb (ed.), Peer Interaction, Problem-solving and Cognition. Multidisciplinary Perspectives, International Journal of Educational Research. Vol. 1, No.13, 89-99.

Slater, T.F. (2003). When is a good day teaching a bad thing? Phys. Journal of Teacher Education. Vo. 41 No.7:437-438.

Vygotsky, L. (1978). Mind in Society: The development of higher psychological processes. Cambridge, MA: Harvard University Press. PP.86. 


\section{Biographical notes:}

Dr. Asrat Dagnew Kelkay has got his first degree in pedagogical science at Bahir dar University. He has attended his second degree in Addis Ababa University in curriculum and instruction 1992. At Andhra University, he achieved his ph.D. He published more than 12 articles in the international reputable journals. He is an associate professor in education by now. As quality assurance coordinator, department head and course chair, Dr. Asrat contributes too much in Bahir dar University. He is an effective teacher in the department of teacher education and curriculum studies. 